\title{
BREAKING THE ISOLATION: FILIPINO LIVE-IN CAREGIVERS' EXPERIENCES OF SETTLEMENT IN TORONTO
}

\section{By}

Chantal Dansereau-Cahill, B.A, McGill 2007

\begin{abstract}
A Major Research Paper
presented to Ryerson University
\end{abstract}

in partial fulfillment of the requirements for the degree of

\author{
Master of Arts \\ in the Program of
}

Immigration and Settlement Studies

Toronto, Ontario, Canada, 2010

(c) Chantal Dansereau-Cahill 2010 


\section{Author's Declaration}

I hereby declare that I am the sole author of this major research paper.

I authorize Ryerson University to lend this paper to other institutions or individuals for the purpose of scholarly research.

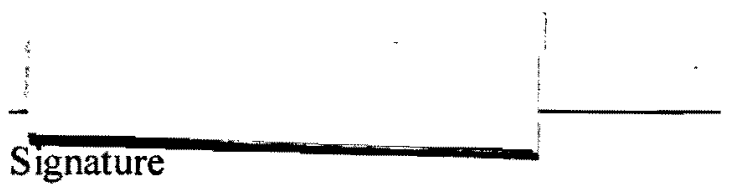

I further authorize Ryerson University to reproduce this paper by photocopying or by other means, in total or in part, at the request of other institutions or individuals for the purpose of scholarly research.

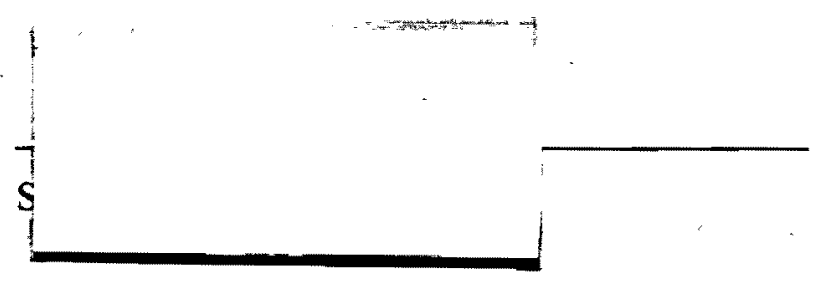




\title{
BREAKING THE ISOLATION: FILIPINO LIVE-IN CAREGIVERS' EXPERIENCES OF SETTLEMENT IN TORONTO
}

\author{
Chantal Dansereau-Cahill \\ Master of Arts, 2010 \\ Immigration and Settlement Studies \\ Ryerson University \\ ABSTRACT
}

This study looks at the agency and activism of Filipina live-in caregivers in Toronto and how they break the isolation seemingly imposed by the live-in caregiver Program and foster their own settlement in Toronto. This research details the problem approach, which puts forward neoliberalism as a great hindrance to the settlement of these women, and contrasts it with the agency approach, which stipulates that agency, resiliency, resistance, and social capital are also important forces in shaping their experiences in Toronto. Four in-depth interviews were conducted and the main themes that transpired were religion, family, the desire for normalcy, and developing community networks mainly, but not necessarily exclusively, within the Filipino community. Policy implications include encouraging grass-roots associations to promote informal socializing during evenings or week-ends, when caregivers have time to participate in activities outside of their work.

Key words: Live-in Caregivers, Filipina, Settlement, Agency, Immigrants. 


\section{Acknowledgments}

I would like to thank Dr. Vappu Tyyskä for her academic supervision, guidance and support. I would also like to thank Terry Olayta of the Caregiver Resource Center in Scarborough for hosting a dinner party where I was able to meet and later interview participants for this study. In addition, I am grateful for the time and willingness of participants to share their experiences with me.

Special thanks to my parents, my sister Melanie, my partner Evan, and all my friends who patiently listened to me when I faced challenges in the completion of this major research paper, and for their unconditional support.

Finally I would like to thank Robert, gate agent at the Winnipeg International Airport, who went above and beyond what is expected of him to retrieve my notes that I had forgotten onboard an aircraft. 


\section{TABLE OF CONTENTS}

Title page $\quad$ i

Author's Declaration

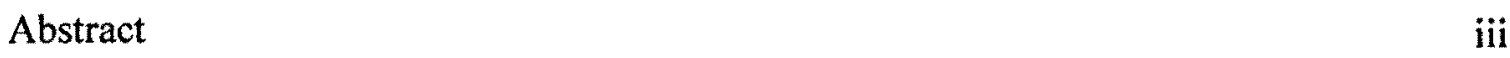

Acknowledgements

Table of Contents $\quad v$

List of Appendices $\quad$ vii

Introduction $\quad 1$

Background to the LCP '3

Impact on the Philippines and on Filipino families 6

$\begin{array}{lr}\text { Theoretical Frameworks } & 10\end{array}$

$\begin{array}{ll}\text { The Problem Approach } & 10\end{array}$

The Agency Approach 18

$\begin{array}{ll}\text { Social Capital theory } & 19\end{array}$

Resistance $\quad 21$

Resiliency 2 26

$\begin{array}{ll}\text { Research Focus } & 28\end{array}$

Research Methods $\quad$ : 30

Results and Analysis $\quad " 33$

Religion .33

Family $\quad 34$

Desire for normalcy $\quad$. 36

Developing Community Networks _. 38

Conclusion and Recommendations $\quad 41$

Appendix A . 43

$\begin{array}{lll}\text { Appendix B } & 44\end{array}$ 
Appendix D

References 


\section{List of Appendices}

Appendix A: Recruitment Flyer

Appendix B: Consent Form

Appendix C: Basic Demographic Information Form

Appendix D: Interview Guide 


\section{INTRODUCTION}

The Live-in Caregiver Program (LCP) has received a lot of media attention in the recent months. In March of last year, the story of Filipina Joelina Maluto, who was lured to Toronto under promise of a job only to be imprisoned in her recruiter's basement and pressured to work illegally, exposed the widespread abuse of women being assured non-existent jobs in Canada (Brazao, 2009). A few months later, Liberal MP Ruby Dhalla was compelled to resign after the two Filipino live-in caregivers hired to care for her elderly mother reported being abused. They claim their passports were withheld, that they were forced to work 12 to 16 hours a day and that they had to perform duties totally unrelated to their work, such as shining shoes, washing cars, shovelling snow, and cleaning offices that belonged to the Dhalla family (Bielsky, 2009). The LCP has been portrayed in a very negative light, and the live-in caregivers, as victims of this unfair federal immigration policy.

This study analyzes how Filipina nannies in Toronto use their agency and activism to shape their own settlement in Canadian society and give meaning to their lives. The Filipino community around the world, among which caregivers are prevalent, has often engaged in widescale public displays of activism. The execution of Flor Contemplacion in Hong Kong in 1997 detailed later in this proposal - sparked an outrage so massive among the Filipinos around the world that "the incident prompted a diplomatic crisis between two Southeast Asian neighbours as both countries withdrew their ambassadors"' (Bakan and Stasiulis, 1997, p.4). Right here in Canada, the Filipino community spontaneously united after the fatal shooting of a 17 year old Filipino youth by the police in Toronto in 2004. Thousands gathered for the funeral and held community meetings to support the family of the victim and launch their own investigation of the incident (Garcia, 2005). Yet few studies have focussed on the individual-level actions of 
Filipina caregivers. This study will look at nannies' actual subjectivity and individual or smallgroup based actions that have shaped their experiences of adaptation and settlement into Canadian society, and the mechanisms used to foster interactions and to give meaning to their lives. This study, which brings-in original research through four in-depth interviews with current and former Filipina live-in caregivers in the Toronto area, hopes to promote a deeper understanding of their social and political activism and a greater appreciation for the agency with which they shape their own settlement in Canadian society.

The literature on the LCP is plentiful. It covers topics ranging from the global neo-liberal economic forces that have made the LCP so popular among both Filipinas (Ehrenreich and Hochschild, 2002, Parrenas, 2002) and Canadian families (Pratt, 1999, Bakan and Stasiulis, 2005 ) to the widespread abuse, violence and isolation they continue to endure (Arat-Koç, 1997, Bakan and Sasiulis, 1997, Spitzer and Torres, 2008). Research has also been conducted on the requirements intrinsic to the LCP that renders nannies vulnerable to abuse (Oxman-Martinez, 2004, Spitzer and Torres, 2008); the impacts of such massive female migration on the families left behind (Parrenas, 2002); the feminization (Spitzer and Torres, 2008); racialization (Bakan and Stasiulis, 1997); commodification (Dyer, 2008); internationalisation (Yeates, 2005); and devaluation of care (Cheng, 1999); and the widespread deskilling of these women and their children once in Canada (Pratt, 2008). After a brief historical background to foreign domestic work in Canada and an overview of the themes mentioned above, this research paper will engage the issue of adaptation through two theoretical frameworks, namely the problem approach and the agency approach. 


\section{BACKGROUND TO THE LCP}

The need to import domestic servants to Canada is not new. The LCP is but the latest version of programs intended to bring people from outside Canada to care for our nation's children and elderly. Under the British Women's Emigration Agency, 8,500 British women had their passage paid to Canada between 1884 and 1914 (Schecter, 1998). At the time, these nannies were automatically granted the landed immigrant status. After all, being of Anglo-Saxon background would ensure an entrenchment of British culture and values in the next generation of Canadians, and they were deemed suitable to become wives and mothers in this country (Bakan and Stasiulis, 1994, Macklin, 1994, Spitzer and Torres, 2008). After the Second World War, the source countries for domestic work shifted to Non-Jewish single women or widows from Eastern Europe (Bakan and Stasiulis, 1994, Arat-Koç, 1997, Harzig, 2003). Canadian authorities took advantage of the vulnerability of the displaced women in refugee camps, and cherry-picked applicants of Baltic origin and Protestant belief (Harzig, 2003). Nevertheless, the supply consistently failed to meet the high demand for this type of work. No regulation ensured that the women actually stay in domestic work once in Canada, so many switched to more rewarding occupations (Giles and Arat-Koç, 1994).

The introduction of the West Indian Domestic Scheme - also called the Caribbean Scheme (Macklin 1994) - in 1955, attempted to resolve this problem. Approximately 3,000 women from Jamaica and Barbados were accepted in Canada on the condition that they remain in live-in domestic service for at least one year (Bakan and Stasiulis, 1994, Macklin 1994, PCHRD, 1997,

Schecter, 1998, Oxman-Martinez et als. 2004, Spitzer and Torres, 2008). Applicants had to be single and without dependents (Macklin, 1994). The desire for a nanny with a lack of family commitment accentuates the possessiveness of the master-servant relationship and exposes a 
"resolute apathy towards women migrants of colour who might someday attempt to settle in Canada" (Macklin, 1994, p.16). These caregivers were also subjected to medical testing for venereal diseases, and this testing served to stereotype Black women as sexually promiscuous (Macklin, 1994, PCHRD, 1997). Governmental policy required that they live-in with their employer, thus rendering them vulnerable to the worst exploitation and stifling their ability to create new social networks (Macklin, 1994). The hierarchies within the caregiver category became more elaborate as they were now based on country of origin, language, religion and race. Black domestics were also paid less than white domestic servants from Europe (Bakan and Stasiulis, 1997). These regulations clearly implied that these women were undesirable and temporary additions to Canadian society. The Canadian government made sure to include a provision for the return of these women to their home country should they be found unsuitable for domestic work (Bakan and Stasiulis, 1994). However, as long as they fulfilled the one-year of live-in care work requirement, they would be granted permanent residency.

In 1973, the Canadian government entered its most restrictive phase with the instalment of a system of temporary work visas, which could be renewed annually as long as the person was still employed as a domestic worker. This new structure effectively halted the allocation of permanent residency status to domestic workers, whom could no longer hope of ever becoming Canadian citizens (Macklin, 1994). It also ensured that those who had sought better employment in Canada did not have their visas renewed and were forced to return to their countries of origin (Bakan and Stasiulis, 1994). This structure rendered domestic workers cheap, exploitable and disposable.

In 1981, the case of the 'Seven Jamaican Mothers' effectively modified the federal policies pertaining to foreign domestics. These seven applicants had not declared having children in 
order to enter Canada as domestics, an omission which was revealed later when they tried to sponsor these 'nonexistent' children (see Macklin, 1994). The court ruled that they were allowed to stay in Canada, and the creation of a new scheme ensued, entitled the Foreign Domestic Movement (FDM) (Macklin, 1994, Schecter, 1998). The FDM lifted the exclusion of married applicants and stipulated that the applicant must possess at least one year of experience as a domestic worker or a certificate attesting to the completion of a domestic worker training program. As well, there were changes to allow for nannies to apply for landed-immigrant status from inside Canada. Indeed, a domestic worker could apply for landed status if they completed two years of employment within their first three years in Canada, had favourable reports from their employers and demonstrated up-skilling, such as the completion of a part-time night class in a specific trade (Macklin, 1994). The FDM sets the guidelines for what was to become the LCP in 1992.

- Under the more flexible LCP, domestic workers must now possess the equivalent of a grade 12 and at least six months of full time training. They no longer have to obtain 'release letters' from their employers and no longer have to show skill upgrading in order to apply for permanent residency status (Ibid). When they arrive in Canada, they are now directed to a counselling session where rights, responsibility and recourse are explained to future live-in caregivers. This mandatory information meeting is an attempt to reduce abuse (Ibid).

In the light of recent scandals, there have been amendments to the LCP in the hopes of making caregivers' rights clearer. For example, the time within which they must complete 24 months of full-time work has been increased from three to four years. Also, the employer must pay for the caregiver's health insurance at no cost to the caregiver until he/she becomes eligible for provincial health insurance; enrol the live-in caregiver in provincial workplace safety 
insurance (also known as workers' compensation); pay for the services, fees and costs of a recruitment or third party agency if they are using one for recruiting purposes, and are not permitted to recoup these costs from live-in caregivers (HRSDC 2010).

Whether or not the increase in the time given to complete 24 months will in fact sway live-in caregivers to leave abusive situations is yet to be determined. Other factors will always come into play: the lack of financial resources to sustain themselves between employers; the lack of an organisation dedicated to help nannies in times of crisis; the lack of knowledge about what options they have to help themselves in case of abuse; and fear or being left out on the street. The fact that employers are told that they are not allowed to keep the live-in caregivers' passport or work permit does not necessarily prevent them from doing so, and the power dynamics between employer and employee leaves little room to manoeuvre for the live-in caregiver.

\section{Impact on the Philippines and on Filipino families}

One of the themes often analysed in the recent literature is the deep impact of such massive migration on the economy and society of the Philippines. In the last decade, the Philippines have become a prominent source country for women in the LCP. Indeed, they represent $83 \%$ of the 36,640 live-in caregivers to enter Canada between 1993 and 2006 (CIC, 2006). Although strong preference continues to be given to unattached applicants, $25 \%$ of these women have declared themselves as married or in a common-law relationship (Spitzer and Torres, 2008). From an economic point of view, approximately half of the country's population is sustained by remittances from migrant workers, totalling almost $\$ 7$ billion in 1999, making women's care the country's primary export (Parrenas, 2005). Often, these women are from a well-educated middle class in the Philippines, yet can earn more income by working as a nanny in Canada. From a 
societal point of view, the consequences can often be tragic. A lot has also been written on the impact of this 'care drain', where Filipina mothers leave their own children behind to care for someone else's children (Ehrenreich and Hochschild, 2002, Parrenas, 2002, Bakan and Stasiulis, 2005 , Yeates, 2005). An estimated $30 \%$ of Filipino children have at least one parent who has left to work abroad (Ehrenreich and Hochschild, 2002). These children of migrant workers are found to express anger, confusion and apathy, and have higher rates of delinquency, child suicide, and school drop-out (Ibid). One of the results of Parrenas' (2005) in-depth interviews with sixty-nine young adults who grew up in transnational households in the Philippines reveal that an unstable family life has led many to use drugs, gamble and drink. Although not all see their mother's migration as abandonment, her findings definitely point to significant emotional hardships, and some admit to being jealous of the children their mothers now care for in Canada (Spitzer and Torres, 2008). Sadly, almost none of these children had yet reunited with their migrant parent; some hadn't seen their parent in over ten years (Parrenas, 2005). The impact of such separation is profoundly felt by the nannies/mothers as well, who sometimes compensate for their inability to directly care for their own children by giving all their love, affection, and attention to their young charges in Canada (Ehrenreich and Hochschild, 2002).

Another recurrent topic in the literature has been the deskilling experienced by these immigrant women, who are often nurses, teachers or lawyers by training (Pratt," 1999, Pratt, 2008, Spitzer and Torres, 2008, Kelly, 2008). The working visas issued to Live-in caregivers prohibit educational training, making it illegal for nannies to try to upgrade their skills (Pratt; 1999). After working for two years or more as a nanny, many feel they are no longer competent to work in their field. This, added to the stringent criteria of professional regulatory bodies which make it very hard for any immigrant to have its credentials recognized, leads to many 
women continuing to work as live-in nannies even when they could apply for an open-permit and work in a different field. Also, family obligations in the Philippines often translate into very little savings for settlement in Canada, including upgrading or bridging courses. Remittances are sent back home, and after their two-year contract is over, most must continue to work as live-ins because they have no other choice financially (Pratt, 1999). While $28.3 \%$ of female principal applicants had a university education, only $11.3 \%$ were destined for the types of jobs that require these qualifications (Kelly, 2008).

Reunification is a third theme that has received a lot of academic attention. Difficulties in parenting their own children after years of separation and high drop-out rates for second generation Filipino are issues that newly reunited families can expect to face. Just when they think their long wait and sacrifices will pay off; these women are faced with the harsh reality of reunification. The deskilling they experienced in Canada is proving to persist across generations (Ehrenreich and Hochschild, 2002, Pratt, 2008). Youth who have seen their parents unable to utilize their skills lack motivation at school and see no point of pursuing higher education. Youth of Filipino origin fair among the worst amongst other ethnic groups in terms of High School completion (Kelly, 2008). Moreover, the fact that those migrant women are now the primary bread-winners has deep implications for the gender roles once their husbands join them in Canada. The Philippines is a more patriarchal society, and when reunited with their spouse who has a better knowledge of the language, the city, the job, it can be very stressful for both partners involved. This new sexual division of labour can create conflict, family fragmentation, and a need to redefine social roles (Ibid).

This brief overview of recurrent themes is important in order to understand the context in which the agency of live-in caregivers must operate. In the following segment on theoretical 
frameworks, I will outline the problem approach and the agency approach to live-in caregivers. The problem approach focuses on the impact of neo-liberalism and patriarchy on caregivers, while the agency approach centres on the activism and resiliency displayed by these women, to adapt and shape their future in Canada. 


\section{THEORETICAL FRAMEWORKS}

\section{The Problem Approach}

In this segment, I will outline the factors that make the immigration of live-in caregivers possible and those that thwart their ability to create social networks and thus further isolate them within Canadian society. The problem approach is the dominant framework from which scholars have analysed the situation of live-in caregivers. It tends to pathologize live-in caregivers and portrays them as powerless to shape their future. It emphasises macro-level causes to justify why and how this abusive and exploitative female immigration is possible in the first place. The concepts of 'neo-liberalism' and 'patriarchy' are most relevant in this analysis. I will explain how neo-liberalism created the need for foreign caregivers in Canada and how restrictive and patriarchal immigration policies have simultaneously made them more vulnerable than ever. The inability or unwillingness of government to regulate working conditions of live-in caregivers will also be discussed.

Neo-liberal theory is a set of "political beliefs, values and practices that valorize the private market, economic rationalism, and individual, rather than collective, responsibility for social and individual ills"' (Khor in Baines, 2010, p.12). It is the restructuring of both state and economy, with a focus on self-sufficiency and individual responsibility. Most western industrial states around the world have undergone a neoliberal shift starting in the 1980s and continuing to this day. In the rest of this paper, I use the term 'neo-liberalism' to mean both the theory and the policies that emerged from them. Neoliberalism is a good starting point to explain the current economic and political situation that allowed for the creation of policies that further restrict the physical and professional movement of live-in caregivers. ".: 
One way by which the widespread neoliberal shift in the 1990s affected newcomers is in the provision of social services throughout Canada. The closing of INTERCEDE last March - which had been the leading advocacy group representing foreign domestic workers in Toronto since 1979 - in only one of the tragic consequences of this social, political and economic restructuring.

Neo-liberalism was accompanied by rising anti-immigration hysteria in both the United States and Canada. In the US, the immigration threat, which had previously been of Mexican men stealing jobs from 'true' Americans, now shifted to Mexican women, who were portrayed as only coming to the Unites States to give birth to babies and "soak up social services" (Chang, 2000, p.6). Proposition 187 is one of the many neoliberal immigration policies adopted in the United States during the 1990s that restricted the use of public benefits by undocumented immigrants. It proposed such draconian measures as to ban undocumented children from public schools and deny the undocumented from basic and preventive health care such as immunizations (Chang 2000). Although Proposition 187 was ultimately ruled as unconstitutional, several policies were passed in the following years with similar results, including the Personal Responsibility Act (PRA) and the Illegal Immigration Reform and Immigrant Responsibility Act (IIRIRA). The PRA, which was signed into law in 1996; drastically reduced funding for welfare programs, put a five-year lifetime cap on receipt of welfare benefits, denied aid to children unless paternity is established, and "'barred state and local government from providing all but emergency services to undocumented immigrants", among other measures (Ibid, p.7). The IIRIRA :"reduced judicial discretion in immigration: matters, resulting in the automatic deportation of immigrant convicted of even minor crimes" (Ibid, p.9). The evident goal of restricting basic human rights to immigrants is to curtail the 
immigration of poor undesirable future burdens, yet it also serves to create a vulnerable and exploitable labour force, one who will not complain of sub-standard employment conditions and abuse (Chang, 2000).

In Canada, the threat was mainly directed at immigrants' and refugees' criminality (AratKoç, 1999, p.42). Several neo-liberal policies were put in place in the 1990 s and have had a negative impact on the entry of women as immigrants, among which the introduction of Bill C86 in 1992 and the Right of Landing fee in March 1995. Bill C-86 calls for a focus of the recruitment on professional and business immigrants and increases the use of temporary workers, who, by definition, are not seen as welcome additions to Canadian society (Arat-Koç 1999, p.42). The Right of Landing fee of $975.00 \$$ is very symbolic. Modelled from the Chinese head tax, it emphasizes immigrants as burdens on society, and immigration as a privilege (AratKoç, 1999, Tobani, 2000). It's a practice that discourages low-income immigrants from coming to Canada. Moreover, the government has severely cut financial assistance to the settlement of newcomers. The abolition of the living allowance granted to those taking intensive language training courses has enormous race and gender dimension. The fact that one must now speak English or French before arrival places immigrants from countries where these languages are not spoken, at a disadvantage. In addition, women are less likely than men to learn foreign languages in their home country (Arat-Koc, 1999, p.49). It is still debatable whether the government and the media created a panic in the hope of having anti-immigration legislation passed, or whether the policy passed as a response to the panic, but one thing is certain, as of the 1990s, the atmosphere became one of increased hostility towards immigrants.

One of the core principles of neoliberalism is the limited intervention of the state in economic matters. Domestically, this translates into substantial cuts in the welfare state, thus leading to 
widespread privatization of services that were once provided by the state, decreased funding in education, health care and social assistance. Adaptation has been particularly hard for women, who do most of the care-giving work in society. More specific to my research is the fact that this neoliberal shift has once again delayed the implementation of a national child care policy. There is a big demand for affordable full time child care in Canada, yet the government uses neoliberal principles as excuses not to get involved in what it labels a private matter. To this day, Canada does not have a national day care system. Canadian families with two working parents must rely on a patchwork of schemes to ensure their children are taken care of, one of which is the LCP. To fill the gap created by the successful movement of women to the public labour market, Canada, who boasts that it is a modern and progressive society, must import women from the global South to fulfil the most basic needs of Canadians families (Schecter, 1998).

Moreover, as Ehrenreich and Hochschild (2002) wisely articulate, the presence of immigrant nannies in Canada does not only enable native-born women to participate in the workforce, it also allows for affluent men to continue avoiding doing 'women's work' or the 'second shift'. The devaluation of care work is amply discussed in the literature on the live-in caregiver program. Society continues to view housework and child care as women's responsibility, not 'real' work, and a natural contribution they should make for the good running of the household and of society (Schecter, 1998, Ehrenreich and Hochschild, 2002, Dyer, 2008). Although the feminist movement of the 1960 s brought child care onto the political arena, the limited presence of feminists in the major Canadian political parties rendered this struggle unsuccessful. According to Schecter (1998), the feminist movement of the 1960s might have backfired and entrenched the patriarchal view on division of labour: 
"The institutionalized women's movement, operating within the framework of equality of opportunity, advocated increasing women's participation in the public sphere as the sole route to gender equality. It thus legitimated the idea that work in the public sphere is inherently more valuable than that performed in the private sphere while reinforcing cultural invisibility and masking the economic significance of domestic labour and child care" (p.3).

That being said, the women's movement is not to blame for the present condition of Canadian families forced to participate in this international sexual division of labour by hiring a female nanny from abroad. In the past twenty years, as neoliberal tendencies rose and became more entrenched, the social victories from the feminist era were simultaneously eroded. With the increased desire for self-sufficient and profit-oriented citizens and came a decreased support for both immigrants and women, who were portrayed as needy and burdens. As of the 1990 s, there has been a fierce anti-feminist reaction that can be attributed to neoliberal ideology. Indeed, the Mulroney government cut funding to the National Action Committee which had been fighting to end sex role stereotyping of immigrant and poor women, and started supporting the REAL (Real Equal and Active for Life) Women's claims, which promoted traditional female roles within the family and believed only a child's real mother, living at home, could care for a child (Schecter, 1998, p.133-134). By cutting financial allocations to social services and therefore forcing mothers to either work longer hours to pay for child care or forgo paid work completely and stay home to care for their children on a full-time basis, several gains previously made by the feminist movement were lost (Ibid).

Racism also prevails in immigration legislation and practices. Immigrant women of colour in Canada tend to be segregated in traditionally feminine roles such as nursing and care-giving. Although the demand for nurses is very high, no points are attributed to nurses under the point system, nor is it listed as a desired occupation. Filipina nurses, unable to enter Canada as 
independent immigrants, commonly come in through the live-in caregiver program, and then are stuck in underemployment for years, if not for life. The issue of credential recognition is larger and more complex than what can be dealt with in this paper. Yet for the present purpose, it is important to acknowledge that foreign-born women have come to be associated with care work, as "native-born women simply refuse to do it for the wages and working conditions offered by prospective employers" (Giles and Arat-Koç, 1994, p. 15).

As we can see from the previous accounts, patriarchy and racism continue to prevail in the experience of live-in caregivers. The prohibition for live-in caregivers to work for more than one employer or on a live-out basis attests to the desire to control and 'possess' their female and racialized employee, a good example of both patriarchy and racism at play.

There are several difficulties in regulating the working conditions under the LCP. First of all, it is hard to define exactly what constitutes 'work'. As Yeates (2005) accurately pin-points, care labour is extremely diverse. It accommodates a wide range of activities (caring for children, cleaning, cooking, bathing, etc.), and "embraces groups with different skill levels/ occupational positions, working in different settings under different conditions"' (p.228). When care work is privatized, it is not conceptualized as work and is seen as a natural part of family life. It is hard to define exactly what constitutes 'work' and what tasks that would have been done regardless of employment. Secondly, it is hard for the state to regulate and monitor what goes on in the privacy of one's own home. The private, gendered and flexible nature of domestic work seems to place it outside the realm of standard labour laws and social protection (Ehrenreich and Hochschild, 2002, Oxman-Martinez et als. 2004, Spitzer and Torres, 2008). Thirdly, although admission to the LCP is federally regulated, employment legislation (minimum wages, overtime payment, maximum hours of work, worker's compensation, health benefits, etc.) falls under 
provincial jurisdiction and therefore varies by province (PCHRD, 1997, Spitzer and Torres, 2008).

Under these conditions, it becomes very hard to have enforceable working and living standards for the immigrants that come to this country under the LCP. Intrinsic to the LCP come the requirements for nannies to live with their employers, to immigrate alone and not with their family, and to provide twenty four months of servitude before being granted the right to apply for permanent residency. If living in the employers' home was made optional and if they were free to change employers, the workers could leave an abusive employment situation without risking their status in the country or having to pay to change employer (Velasco, 1997, p.161). The LCP was set up to address only the needs of employers for cheap and efficient child care and elderly care (Ibid). It seems as though the government and Canadian families stand to gain by having ambiguous and confusing policies concerning live-in caregivers. Although recent changes in legislation attempt to clarify the rights and responsibilities of live-in caregivers, they seem to give fewer rights and anticipate more responsibilities on the part of caregivers. The problem approach draws on these difficulties as causal explanations for the isolation and demoralization of live-in caregivers.

The main critique to the problem approach is the fact that it leaves little room for individual or collective action on the part of live-in caregivers. As I have demonstrated, many authors hint at the fact that macro-level forces isolate live-in caregivers in their employers' homes and render them helpless to shape their future in Canada (Ehrenreich and Hochschild, 2002, Spitzer and Torres, 2008). However, in the following section, I will draw on other authors to show that this is not the case (Baines, 2008, Baines, 2010, Fudge, 1997, Velasco, 1997). 
Another critique stems from the fact that biases against domestic workers have always existed. Indeed, as previously explained, the need for domestic care workers in Canada is not new, and the main challenge with all the previous immigration schemes has been the retention of women in this type of employment. I believe that neoliberalism did not cause the isolation of live-in caregivers, but the effects of the policies and practices instituted under its framework simply perpetuated a discrimination that has always existed. What is different from before is that these women are largely from racialized groups. As pointed out before, racism is deeply embedded in the whole immigration scheme, with the underlying assumption that they will be more obedient, submissive and grateful than their white counterpart.

Nevertheless, mistreatment of live-in caregivers is all too real and all too frequent. It is a recurrent theme in the literature on the subject of foreign domestic work. Most live-in caregivers come to Canada in the hope of becoming permanent residents, and are therefore required to work as domestic servants two years out of their first three in this country. As it can take several months to find a new employer if they get fired or quit, it is to their advantage to stay with the family they are first assigned to, placing them in a very vulnerable position. Accounts of physical, psychological, financial and sexual abuse under the LCP abound. They can take the form of overwork, underpay, not being paid for overtime, asked to perform unrelated tasks, not being given sufficient privacy or food, or being victims of derogatory comments, physical violence or sexual abuse (Macklin, 1994, Giles and Arat-Koç, 1994, Arat-Koç, 1997, Bakan and Stasiulis, 1997, Daenzer, 1997, PCHRD, 1997, Schecter, 1998, Ehrenreich and Hochschild, 2002, Oxman-Martinez et als. 2004, Spitzer and Torres, 2008). Most often, they do not complain to their employer for fear of losing their job or facing harsher treatment, or to the government, for fear of being deported (Oxman-Martinez et al. 2004). Some might feel in debt to their 
employer who has given them a job, others have suffered worse abuse in previous countries such as the in Singapore or the Middle East, and feel relatively lucky to be in Canada (Ibid). Their subordinate positions as racial minority women, working in a devalued occupation, of uncertain citizenship status, and physically and occupationally confined, are all factors that compound the impact of oppression (Daenser, 1997, Schecter, 1998).

The problem approach, with neoliberalism and patriarchy as its foundations, understandably portrays live-in caregivers as caught in a web of macro-economic and societal forces leaving them powerless to shape their future in their new country. However, as the next section will demonstrate, these women show resiliency and adaptability in the face of the harsh conditions

they must endure.

\section{The Agency Approach}

The global economic and political forces previously mentioned have indeed created an undue burden for immigrants in general and immigrant women in particular. The mostly constraining legislative requirements intrinsic to the Live-in Caregiver Program have rendered these women isolated, dispensable and exploitable. However, these hardships have also led to creative ways to coping on their part. These creative means of dealing with their situation fall under the social phenomenon called agency.

Agency, as defined by Athabasca University's Dictionary of the Social Sciences (2004), focuses "on the individual as a subject and view social action as something purposively shaped by individuals within a context to which they have given meaning"'. The defining quality of action is that, unlike behaviour, it carries a subjective meaning for the actor. Social capital, resistance, and resiliency are three forms of agency useful in understanding this perspective. 


\section{Social Capital theory}

Robert Putnam is often credited as the father of social capital theory, although others such as Bourdieu, Coleman and Tocqueville all contributed to the body of literature on the subject, with more or less academic rigueur and quantitative focus (Schuller et als. 2000). In his landmark article Bowling Alone (1995), Putnam uses the analogy of physical capital and human capital tools and training that enhance individual productivity - to relate to social capital, which he defines as "features of social organization such as networks, norms, and social trust that facilitate coordination and cooperation for mutual benefit" (p.66). In his wide-ranging follow-up book sharing the same title, Putnam (2000) emphasizes reciprocity as a central component of social capital. Building and sustaining networks, norms and trust are not goals in themselves, they are instrumental in reaching common objectives. Putnam strongly believes the life in high social capital communities is better. Basing his claim on his own 20-year study of different regions in

Italy, Putnam believes that such things as voter turnout, newspaper readership, membership in choral societies and football clubs, are the features of a flourishing community. He argues that "these networks of organized reciprocity and civic solidarity, far from being an epiphenomenon of socioeconomic modernization, were a precondition for it" (Putnam, 1995, p.66).

Putnam set out to measure social capital in every state in the United States, with the help of 14 indicators including 'number of club meetings attended in the last year', 'number of group memberships', turnout in presidential election', 'number of times did volunteer work last year', and 'agree that most people are honest'. He found that the 1960 s witnessed a significant drop in reported weekly churchgoing; voter turnout; trust in the government; union membership; parent teacher organisations; and a decrease in membership in civic volunteer organisations like the 
Boy Scouts or the Red Cross, and fraternal organisations such as the Shriners or the Masons (p.69-70). And the trend continues into the 1970s; 1980s and 1990s.

He posited several factors as responsible for this decrease in social capital in the United States, namely the entry of women in the labour market, which reduces the time and energy needed to build social capital; residential mobility, as it takes time for individuals to put down new roots in a new community; other demographic changes such as fewer marriages, fewer children, lower real wages; technological transformation of leisure, such as the entry of television in Americans' homes, and generational changes, the latter two on which he places the most onus (Putnam, 1995).

The concept of social capital also implies predictability. For example, it could lead us to believe that by simply increasing the networks and levels of trust of Filipina caregivers in Canada in relations to other Filipina caregivers and in relations to their communities in general, the outcomes in terms of quality of life would automatically be greater. There are several reasons why that might not be accurate or possible.

Critiques of the social capital theory are numerous. Most importantly, Putnam's research has been condemned for its focus on White, middle-class, American families (Schuller et al., 2000, Arneil, 2006). His work does not take into account the rapidly changing face of the United States. There still is a profound racial bias, and Hero (2007) attempted to find out if more social capital is necessarily better for everyone, regardless of race. He did so by systematically and empirically analysing the social capital argument through the lens of racial diversity. He noted that Putnam's study of the decline in social capital in the United States in the 1960s and 1970s coincides with the emergence of formal racial equality. Studying Black and White differences, 
within and across states, he found that racial diversity and social capital are "intertwined and somewhat negatively related" (p.73). He found that high social capital communities tend to be homogenous and White and he could not find one community that has high levels of racial diversity and high levels of social capital. Putnam himself had hinted on the notion that increased diversity might actually decrease social capital, yet had not empirically analysed this situation.

Another critique of the social capital theory is that it is overly versatile (Schuller et al., 2000). Indeed, it can be deployed to a huge range of social issues including economic development, families and youth behaviour problems, schooling and education, community life, democracy and governance, health, crime, environment, and many more (p. 25). Schuller et al. (2000) pertinently wonder if "such versatility (can) be justified, or must a concept that can be deployed in so many different contexts and at so many different levels be inherently incoherent, or alternatively trivial, as an analytical devise?"' (p.25).

That is not to say that the concept of social capital needs to be totally discredited, simply that its critiques must also be acknowledged, and the particular standing of racialized women newcomers be taken into account when discussing policy-making options. It is too simplistic to assume that increasing the social capital of live-in caregivers would automatically erode the power relations at play within the Live-In Caregiver Program and make their adaptation and integration to Canada an easier experience.

\section{$\underline{\text { Resistance }}$}

The next important concept to engage with when looking at the agency of newcomers is 'resistance'. Resistance has also been applied to settlement workers and immigrant communities 
as they try to retain a certain degree of latitude for personal and collective agency in this growing neoliberal world. Indeed, workers in the settlement sector have not remained passive victims in the face of their changing workplace. There are several documented cases of subtle or more obvious forms of ópposition. The concept of 'resistance' is very different in the public/government and private economic sector. In the private sphere, it mostly involves minor infractions of rules, open advocacy or voiced discontent aimed at management. In the public sphere, where workers have a strong identification with the caring mandates of their agencies, a certain amount of professional discretion, and often; a gendered and racialized sense of moral obligation to provide care, the target of workplace resistance is more abstract (Baines, 2008, p.124). Work-specific employers are rarely the primary target of workers' resistance; their aim is towards restrictive funders, premarket governments, and a wider, uncaring, gendered and racialized society (Ibid).

One act of resistance is when settlement workers continue to provide services to individuals who do not meet the eligibility criteria. In his research on the experiences and practices nonprofit organizations providing services to immigrant and refugee communities in Minneapolis, Trudeau (2008) found that 38 organizations $(73.1 \%)$ had eligibility requirements for their social service programmes, and 14 organizations followed the policy of never turning away a person who comes to them for help (p.2816). This is a widespread practice, stemming from the beliefs in universalism of care and the inhumanity in turning away someone who is seeking aid. Workers must not document or report their work with ineligible individuals, as it would not be approved by their funding sources. The other organizations had different ways of dealing with ineligible people. Some refer them to other organizations that could better serve their needs; some provide services through discretionary funding from charitable foundations or fundraisers; 
others provide non-programmatic (and unfunded) services, including transport, acting as an interpreter to schedule meetings, translate documents, assist with job search, etc. (Ibid). This practice "highlights the ways in which organizations negotiate the interface of multiple responsibilities", as they have duty to both government agencies and the communities they serve (Ibid, p. 2817).

Another act of resistance, documented by Baines (2008) in her study of female Aboriginal social workers and social workers of colour, is the rise of new culturally sensitive practice skills. Many First Nations workers and workers of colour are employed in ethnically specific programs or agencies, and find themselves expanding their skills in ethnically-specific areas, reflecting the general under-resourcing of these groups in general, and simultaneously deskilling in the same areas as their white counterparts (Ibid). For example, by virtue of their ethnicity and knowledge of a specific language or culture, they were often called upon to interpret or translate on the job, which requires extensive knowledge of how to convey social nuances, empathy and support across language barriers, and to explain cultural issues. They reported engaging in more outreach work for their organizations, hoping that increased client demand might pressure the government to allocate more funding, and doing more unpaid overtime and volunteer work. While white workers tended to see their unpaid and volunteer work as a form of resistance to the oppressiveness of the current setting, "most First Nations workers and workers of colour saw these activities as part of a lifetime commitment to challenge social oppression" (Baines, 2008 p.128). The fact that these women had to start off with a higher level of skills to be hired in the first place, and their marginalized position in society in general, are two factors that might be responsible for placing them in a better position to tackle neo-liberal intrusions in their work and manoeuver around certain requirements in order to provide the best possible services to their 
clients and find satisfaction in their jobs. However, it appears they have correlated resistance and exploitation. Although they may believe "they are protesting against a socially unfair world", the fact remains that they are extending their work day, sacrificing their family life, health, and sometimes life, for no additional benefits (Ibid, p.128). Upon further analysis, however, comes the realization that historically, many forms of resistance can be linked to self-exploitation as well. After all, suffering does not stop when office hours do.

First Nations services have a special consideration. The liberal human rights approach that advances the autonomy for First Nations people was in place before the current neoliberal framework of homogenization and downsizing. First Nations workers have the right to create new departments and services to deal with problems faced by their own communities, and have the opportunity to incorporate traditional approaches into their work such as healing circles. They better achieve and incorporate skills such as thinking, planning, creating, problem-solving . and program development (Baines, 2008).

Yet another act of resistance, also documented by Baines (2010), is the adoption of a form of . unionism known as social unionism. With neoliberalism changing the ideology, structures and methods in the non-profit workplace, social services can be stripped of their collectivist content and delivered in bureaucratic and uniformed ways that demobilize and disempowered both the workers providing the services and the clients receiving them (Baines, 2010; p.11). Social; unionism has allowed frustrated workers to initiate new processes through which to have a voice in broader issues such as community development, social justice, and economic equity. This model has been called social or community unionism to distinguish it from business unionism, whose sole mandate is to address workplace concerns such as wages. It is the official discourse : . of unions who represent predominantly female workers, and it pursues issues both within the 
boundaries of the workplace - advocating for diminished case loads and improved quality of service - and beyond - such as campaigns for universal health care, fare wages, universal childcare, antiviolence programs, and overall social development (Ibid). Between 2002 and 2006 , union density in the community service sector grew from $35.6 \%$ to $38.7 \%$, compared to a stable $29 \%$ of union density for the total Canadian workforce in the same period (Ibid, p.18). People alienated from the decision-making process chose unionization as a form of resistance and in the hope of having input in policy and practice. Unionizing was seen as a way to recreate and extend the voluntary spirit of non-profit organizations.

However, the resistance strategies of government or non-profit sector employees are not always applicable to individual immigrants. The fight for the rights of domestic workers to unionise is a long and hard one. In 1993, the New Democratic Party, pressured by women's associations and committed to a social equity agenda, legally recognised the rights of domestic workers in Ontario to unionise (Fudge, 1997, p.119). However, this small and symbolic victory was soon reversed. With the arrival of the conservative government in 1995 , collective bargaining rights were once again withdrawn from domestic workers in Ontario, with the reasoning that "where employees work alone, they are not eligible to organize and bargain, because, under the Act, there must be more than one employee for collective-bargaining to be viable" (Ontario Ministry of Labour in Fudge, 1997, p.120).

That being said, caregivers have been forming associations to overcome their isolation and. fight for better working conditions since 1901, when they first lobbied in mass for a minimum wage (Ibid, p.122). The fight for minimum wage has been a very long one. In 1920, under the Farmer-Labour Alliance which defeated the Conservatives to form the provincial government, minimum wage legislation that included domestic workers was finally drafted. The goal was to 
provide better pay for women and children in the province. Yet to insure the passage of this controversial bill, the Farmer-Labour Alliance had to drop the provision concerning domestic worker, ironically eliminating the biggest group of women workers (Ibid, p.123).

A discussion of domestic workers' rights sporadically entered the political arena over a period of time, and Fudge (1997) identifies peaks during the resurgence of unionism in the late 1930 s, and after a massive wave of strikes in 1943, yet no substantial gains were made pertaining to the organization of caregivers until the late 1970s, in the mists of the "Seven Jamaican Mothers" scandal discussed previously. The late 1970s saw a wave a deportation of domestic workers, mostly from the Caribbean, and massive campaigns mobilized both women and workers' groups, and the immigrant community in general. "Save the Seven Mothers", and "Good enough to work, good enough to stay" were two campaigns organized in Toronto, and groups that support landed immigrant status took roots in Montreal, Ottawa, and Vancouver (Schecter, 1998, p.115). INTERCEDE, which had been founded by a group of women lawyers and academics to stop the exploitation of women, now recruited domestic workers as active members, and, in 1984, received their first core funding from the government. . .

\section{Resiliency}

The literature on the concept of resistance tends to focus on group agency: whether it be of employees in the settlement sector, organizations advocating for the promotion of domestic workers' rights, or immigrant families as a unit of analysis. It does not seem to include individual immigrants. The concept of 'resiliency', which is a third facet of agency, may .; partially solve this problem. Resiliency has often been used to characterize immigrant youths' coping strategies in the face of generational conflict, limited financial resources, changing gender roles and new identity formation (Barrera et als. 1998, Tyyskä, 2000). Resilience can be 
defined as "the ability to bounce back from stress and crisis... Individuals, families and communities demonstrate resiliency when they build caring support systems and solve problems creatively"' (National Network for Family Resilience, in Tyyskä, 2010, p.12).

McCubbin et al. (1998) set forth the Resiliency Model of Family Stress, Adjustment and Adaptation, which emphasizes the importance of "ethnicity and culture as critical aspects of family adaptation and particularly in the appraisal and relational processes families use to manage change and adaptation" (p.5). In other words, they try to find out what makes some families more resilient during stress than others. The adjustment phase of their model is determined by many interacting components: the stressor and their severity, family vulnerability and pileups up demands, family typology of establishes patterns of functioning, family resistance resources such as stability, cohesiveness, flexibility, open communication and routines, family appraisal of the stressor, family problem-solving and coping, and family response (p.6-10). Although the authors studied immigrant families faced with an illnessinduced crisis, these components can be applied to the situation of live-in caregivers, who are also immigrants faced with a crisis, a crisis of being uprooted, isolated, and in legal limbo.

Under the Adaptation phase, the authors emphasize the importance of family integrity, unity, flexibility and predictability. Yet all these factors are lacking when it comes to live-in caregivers, who are physically removed from their families and unable to predict when or if reunification will occur. This subject is analysed more in-depth in the Results and Analysis section of this paper. 


\section{RESEARCH FOCUS}

There is a gap in the literature on the personal struggles and possible success stories of live-in caregivers' settlement in Canada. We know very little on how they break the isolation intrinsic in the LCP. On a daily basis, they can be seen in small groups with their respective charges, socializing while the children play at the park. This is especially true in summer months, when they can be outside most days. I assume this type of informal socializing applies less to live-in caregivers hired to care for an elderly person, as they would be indoors most of the time, or those live-in caregivers in remote or rural areas with a small or dispersed population of live-in caregivers. I have also heard about nannies who get together with ten or twelve others and rent themselves an apartment. They spend their days off there, to physically remove themselves from their work place and to socialize away from their employers. These types of anecdotes attest to individual-level activism, and systematic academic research definitely needs to be done on this issue.

At the community-level, the creation and running of organizations dedicated to the promotion and protection of the rights of Filipino domestic migrant workers - such as INTERCEDE in Toronto and PINAY in Montreal - has been analysed by academics (Fudge, 1997, Bakan and Stasiulis, 1997, Oxman-Martinez et als, Spitzer and Torres, 2008). These organizations support, shelter, and counsel Filipino caregivers in need (Fudge, 1997, Oxman-Martinez et als. 2004). They are a great source of support and provide a forum in which LCP workers can socialize exchange information, material, and emotional support (Spitzer and Torres, 2008). They are also the avenues through which information concerning what is happening in the various Filipino communities' abroad, working conditions and legal aspects of being a live-in caregiver, or any other news is dispersed. 
Live-in caregivers have also been known to engage in spontaneous public displays of political activism. Calls for fundamental changes to the LCP and for a stop to deportations have united care workers, community organizations and leaders, academics, and the general population, and have led to many public demonstrations of community activism and agency in Toronto, Montreal and Vancouver (Ontario, 2006, Garcia, 2004). The shooting of a 17 year-old son of a Filipino live-in caregiver in Toronto in May 2004 provoked such a display of community capacity-building effort. Family and several different organizations were unified "to fight for justice in a campaign that also embraced broad social justice issues"' (Garcia, 2006, p.i). Filipino live-in caregivers are also engaged in the political and social activities of their home-country and of the diaspora. The story of Filipino Flor Contemplacion is an example of how transnational links can foster wide scale activism. Contemplacion, a nanny in Singapore visiting a fellow nanny in Hong Kong, was charged with the murder of her friend and of the child she was caring for. As mentioned in the introduction, her execution, in 1997, sparked an outrage so massive among the Filipinos around the world that "the incident prompted a diplomatic crisis between two Southeast Asian neighbours as both countries withdrew their ambassadors" (Bakan and Stasiulis, 1997, p.4). This research attempts to find out how Filipina nannies in Toronto use their agency and activism to shape their own settlement in Canadian society and give meaning to their lives. 


\section{RESEARCH METHODS}

According to Neuman (2008), a qualitative approach is best suited to research that seeks the opinions, feelings and experiences of participants; relies on perceptions and experiences of participants; constructs social reality and cultural meaning; and may test or challenge an existing theory. As the data desired aimed for levels of meaning and understanding that go deeper than mere numbers, the qualitative approach was deemed best suited to the type of information I aimed to gather.

My study will look at how live-in caregivers get to know about the networks mentioned above, why they get involved or why not, and how their involvement (or non-involvement) in these networks affect their daily lives in Canada. This research focuses on the agency and activism used by Filipino live-in caregivers to shape their settlement into Canadian society.

After the approval of the Ryerson Ethics Review Board, recruitment flyers were posted in a community center in Toronto where caregivers typically meet on week-ends (see Appendix A for Recruitment Flyer). Four in-depth interviews with current and former live-in caregivers were conducted between April $29^{\text {th }}$ and May $15^{\text {th }}$ 2009. Participants were between the ages of 29 and 47 and had been in Canada between two and eight years. One participant was interviewed in a room at the Ryerson University library; the three others were conducted in the home of a Filipina activist, and were followed by a communal dinner. All participants were informed that they could refuse to answer any question they did not wish to answer (see Appendix B for Consent Form). A $\$ 30$ compensation was given to each participant and to the activist who put me in contact with three of them, even if she was not formally interviewed. Participants were asked to fill out a few simple questions about their length of stay in Canada, numbers of families they had 
worked for, and if they had any children of their own (see Appendix C for Basic Demographic Information Form).

Following Miller and Crabtree's (2004) format for conducting in-depth interviews, I began with standard biographical questions that call for "short, structured, direct answers" (p.191). These introductory questions, aimed at establishing trust and a climate of self-disclosure, were: "when did you arrive in Canada?", "did you arrive through the live-in caregiver program?", "how many families have you worked for since you arrived?'". If the respondent has had several employers, I will ask: "always in this neighborhood or did they live further away?" If the respondent has only worked in one family or several families but always in the neighborhood, I will ask: "How do you like this neighborhood?" These simple inquiries are very important. They help establish the interview style, build rapport, jog the respondent's memory, build a bridge to intimacy, "assign competence" to the interviewee, provide context data for analysis, and weave a discourse context for the more relevant research questions (Ibid, p.192). Refer to Appendix D for a complete list of questions asked.

I analyzed the data collected using inductive reasoning, meaning that I began with the concrete evidence from my interviews and "work[ed] towards more abstracts concepts and theoretical relationships" (Neuman, 2008, p.60). Because I asked the participants about their daily, face-to-face interactions and encounters among individuals and small groups, my study dealt with the micro-level of analysis (Ibid). The four interviews were tape-recorded, and the first step done was to transcribe these recordings verbatim, in order to give me written record of what exactly was said. Coding was then employed. According to Neuman (2008), coding is two simultaneous activities: data reduction and analytic categorization of data (p.460). The coding of 
qualitative data is done through three phases. The first step is open coding, when I listen to the tapes for the first time and read through my notes to locate themes and assign initial codes, or labels. Secondly, I listen to the tapes several other times while focussing more on the themes than on the data, and staying open to additional codes or ideas that might emerge. This phase is called axial coding (Neuman, 2008, p.462). In this phase, I looked for "causes and consequences, conditions and interactions, strategies and processes, and look for categories or concepts that cluster together" (p.463). In the last phase, selective coding, I scan all the data and previous codes again, and selected cases that illustrated those themes. 


\section{RESULTS AND ANALYSIS}

Several themes arose from the analysis of the data and struck me as particularly relevant in the settlement experiences of to the participants interviewed. In this section, I will expand on these themes, which are religion, family, desire for 'normalcy', and the development of community networks.

\section{Religion}

Religion was a prominent theme that emerged from the interviews. Each participant had their own way of bringing religion into the discussion of their settlement experience. For Lisa (all names are fictitious to preserve anonymity) who worked as a caregiver for four years before obtaining her permanent resident status and becoming a full time student, praying was a mean to keep her going when the employers treated her badly:

L- I am so grateful to God for keeping me alive. I always ask God to give me fortitude, give me strength.

L- I was lonely, the only real comfort were my prayers.

For Beatrice, her prayers were directed at the well-being of her family in the Philippines and their quick reunification in Canada. When talking about her upcoming visit to the Philippines, to visit her sick father, she adds:

B-I just hope the time comes really soon, and that my father will be strong. I hope, I hope, I pray every time that the day [of her departure for the Philippines] will come closer.

For Vera, who never thought she would be the founding member of an association of caregivers and organises weekly sporting events: 
$\mathrm{V}$ - I think it is God who gives it to the deepest in my heart, that we need this, it's for fellow caregivers. Because I'm so lucky with my employer, they're not very lucky.

Religion as a source of strength and a motivator not only to survive but to thrive is not unique to Filipina caregivers, yet it was significantly present in the interviews to warrant special consideration in the data analysis. These practices show a type of resiliency in the absence of family. Since family members are not immediately available for support, these women turned to religious and community practices as their sources of strength.

\section{Family}

The concept of family was also amply discussed in the interviews, mostly in support of the literature on resiliency, which abundantly emphasizes the importance of familial ties for immigrants' well-being, adaptation and integration (Jennings, 2007, Tyyskä, 2010). McCubbing and al. explain that Filipinos tend to view "community networks as an integral and valued part of family life with kinship relation being highly valued and regarded as familial whether defined by blood, marriage or fictive kinship" (p.36). Indeed, the participants interviewed shared a wider more complex definition of family than what is typical in North American culture. They all called older female acquaintances by the name of 'Tita', which means 'aunt', even though no blood relations existed. After a dinner I attended at the private home of a Filipina settlement worker, the guests, who were three caregivers, rose and cleaned the dishes as one would do in a close family member's home, not at a more formal gathering where the host is expected to wash the dishes once the guests have left the house. Beatrice attempts to explain this phenomenon:

B- I call her 'aunt', but it's my father's best friends' wife, something like that. Sometimes, in the Philippines, even if there are no strings attached, you call her 'aunty', like I call 'Tita', well, 'Tita'. 


\section{C- It means 'aunty', right?}

B-Yes, something like that. It's like you respect, it's a way of respecting.

However, the in-depth interview process went a bit deeper in the interpretation of the theme of family. It led me to conclude that although more people are included in the definition of family, the caregivers still miss those close marital or child-parent relations.

B- After five months, I miss my kids, my husband, my family. I cried, for nights...

B- When you have a family, a husband or wife, you can talk to them on the phone, but it's better to talk face to face. Unlike on the phone, I mean, you can fix it up, but sometimes it's hard to catch up on the things they are saying, you say 'ok, ok' but maybe it's a long distance, it cost you a lot.

B- Even though you're having a hard time in your life, but when you're with somebody, like you husband and your kids, it's like battling with a lot of allies.

B- When I see a couple with a kid boy, I imagine it's me and my husband. I see my friends, there are like: 'oh you are looking at them again, you are imagining again, and crying again!'

Although Beatrice seemed much surrounded by friends from her boarding house, and had a very active social life, she gravely missed the connections with her husband, three year old son, and became very emotional in discussing her father. The quality of relationships is vital to a feeling of support and security. The above, however, demonstrates that in the absence of immediate family, the extended family was modified in the settlement experience, providing for a measure of support through fictive kin relationships. Meanwhile, the social capital model is also confirmed, in that these women created new networks which gave them opportunities for further engagement within their own community. 


\section{Desire for 'normalcy'}

Desire for a sense of normalcy was the third theme recurrent in the interviews. Since I am interested in the agency and subjectivity of my research participants, I followed what they seemed to term "normalcy". The yearning to "be normal' is hard to define. What I took out of these interviews was that they wanted to be like everyone else in the mainstream society. I believe this is a coping strategy that fosters settlement. Each participant strived to achieve this through very different means. Lisa found this sense of normalcy though the pursuit of education and volunteering. After she dropped the kids she cared for to school, she would spend hours at the library, reading books and practicing her English. When she left the Program, she continued engaging in the same activities.

L- My joy is to go around, look for books, look for resources that would make my life productive.

L- I volunteer a lot, I don't stop! Since I came to this country, I volunteer at the library, at a center for the elderly, as a counsellor at the CanadianAfrican Association, at schools, I prepare picnics for the kindergarten students...

Lisa had recently attended an information session on the Live-in Caregiver Program in which Minister Jason Kenney spoke. She had a chance to meet him and show him a paper she had written for one of her class on the Program and its pitfalls. Upon receiving praise from the Minister on her achievement and contribution to Canadian society, she said:

L- I really felt so big. I felt elated when he said that. He said those words to keep me going. I kept that signature of him on my essay. And he put the date and said congratulations. I will keep that forever. 
Beatrice found normalcy at the boarding house she goes to every week-end. She had a lot of stressful situations going on in her life: a sick father back home, a husband and young son to support, on top of her duties as a caregiver for two boys here in Canada. She found her sense of normalcy in going out with friends in clubs and explains the feeling this activity brings her by saying:

B-I think it's the one thing that makes my life, you know, ok.

This section is in keeping with the ideas in the resiliency theory put forward by McCubbin et als. (1998). They describe this type of behaviour as a "rhythmic pattern of functioning" (p. 17). Although they use this category to describe families who use "time together and routines as the family's way of maintaining family life in relatively predictable patterns of family living in an effort to cope with life changes", this manner of coping is clearly applicable at the individual level as well (p.17). Beatrice sets up her week knowing that she works from Monday to Friday, and that she gets to go out in clubs with her friend on the week-ends. This is an activity that she chose for herself, which is predictable and on which her employer has little control. In her own words, it makes her life "ok", which I imply to mean "normal", "acceptable", "predictable", and "fun".

This desire for 'normalcy' is also in keeping with the social capital model in that these women also looked for links in the wider society, through various activities that went beyond their immediate ethnic group. These activities include attending religious events, volunteering, going out in clubs, going to school and making friendships there.

\section{Developing Community Networks}


In all four interviews, it struck me how the participants created networks out of sheer coincidence and luck. Each participant had the help of a person or group of people to break out of the isolation of their employers' home, make friends, and begin the slow processes of adaptation and integration, which ultimately was the goal of these women, as all of them plan to sponsor their relatives and make their future in this country.

Lisa encountered the Filipina who would introduce her to community-based events at the library; for Beatrice, it was distant relations of her father who became her boarding family and with whom she attends Filipino community events; for Nina, it was a woman on the bus who first initiated her to the Caregiver Resource Center she regularly attends since; and for Vera, community facilitators were simply the other caregivers she randomly met in the park where she would take her young charges. When asked what it meant to them to have this person (or group of people) with whom to share time with outside of work, the responses were very telling.

L- I feel great! I feel great to be in an organisation like that. It shows that no matter how hard you went through in this live-in caregiver program thing, there are still have lots of possibilities to show and to see. Like for example, some women from the Filipino community, they have great talent. They can dance, they can sing, they can paint, they can do a lot of things that is not sometimes ordinary.

$\mathrm{V}$ - It's a big change in my life to have this kind of friends. It's an experience I never experienced in my whole life. It's really overwhelming that you know that you are helping your fellow caregiver.

$\mathrm{N}$ - I'm so happy, it's really lots of fun, we can get together, I learn more, from other Filipino. We go out, we have a lot of topics to talk about: our life in Canada, about how we sponsor our families from the Philippines.

Beatrice had conflicting views on the subject. On the one hand, she definitely appreciates the friendships she has from her boarding house: 
B- It's like a support, it's good, it's like you're treating them like your best friends, tell them everything that is going on.

These friends and confidants are other Filipina nannies. She is very happy to have them in her life. But on the other hand, she is tired of the superficiality of some members of the community. When she attends outdoor community events, she sometimes feels as if they are trying to show off.

C-How do you feel when you attend these events?

B- Sometimes happy, sometimes not content. Sometimes, some people, they are just there to show something, like you know. Maybe, it's just only in my mind, but like, I see them and they are: 'oh I saw something like this! I bought something like that!' You are there to acquaint, about what's happening in your life, it's not you are there to tell what is new, I mean material things.

C- So they talk about your clothes and stuff like that.

B- hum hum (affirmative sounds) But $80 \%$ it's ok, $80 \%$ it's good.

Also, she is sometimes wary of people from outside the Filipino community. She has a strong self-awareness that she is new to the country and might not know all the customs and ways of acting that are appropriate in different situations.

C- Do you spend time with people from outside the Filipino community?

B- Yes

C- How do you meet these people?

B- ummmm, like not Filipino? Friends of friends, something like that, I don't know, I don't know why I am, so... acquainting so much. But sometimes I am a little bit careful because sometimes you don't know him or her, and I'm just new here.

A lot about social capital can be implied from these comments. Filipina caregivers build different kinds of new networks with others in their own ethnic group. And even though some may be ambivalent about these connections, they also feel similarly ambivalent about connections to the world outside their ethnic community, as was seen in the previous section. In 
total, what emerges is a picture of opportunities for wide engagement, both within and outside the Filipino community.

This study was very revealing in terms of the adaptation and integration of the participants. The boundaries of isolation are huge, stemming from the very nature of the LCP, notably with its live-in requirement, precarious legal status, and forced separation of familial support network, yet the opportunities for community activism and agency are present and realistic. Religion as an anchor, a wider notion of family as support, an effort to maintain their life as 'normal' as possible, and the development of community networks, often unconsciously, are themes that stood out from the interviews as necessary for breaking the isolation seemingly imposed by the Program. 


\section{CONCLUSION AND RECOMMENDATIONS}

This study was designed to solely focus on caregivers' experiences once in Canada, and how they are able to shape their settlement in Canadian society. However, informal discussion and open-ended questions often led the discussion back to their families back home and their attempts to accelerate the reunification process.

Resiliency can be found in each of these women's lives, they are stronger than I could have ever imagined when beginning this study. Resistance strategies were employed at the individual level by organizing activities outside of work, where employers and their families were also welcomed. Vera never would have imagined herself as heading a government-recognized association that promotes health, social interactions and positive employer/employee relations. Yet faced with the isolation of her workplace and the knowledge that so many others so close to her were in the same situation, she started something that will be a part of her community even after she stops being a caregiver.

Social capital theory is also evident in the live-in caregiver context. In the absence of immediate family, the caregivers form new networks with other members of the Filipino community, and somewhat with the mainstream, through membership with organizations, participation in outdoor events such as BBQs, and volunteering with schools, libraries and others. Although they don't replace family relations, they provide these women with necessary social links to engage with the wider society. Putnam's indicators, however, do not resonate with increased adaptation and settlement when it comes to live-in caregiver.

So much research tends to pathologize live-in caregivers, by emphasizing their potential abuse and the hardships felt be their families left in the Philippines. This study attempts to show 
that these women are not hapless victims by focussing on the agency and activism they use to break the isolation and give meaning to their lives. This has policy implication as well. Grassroots community-based associations are vital, and don't require a specific office or staff, as the starting of an association by Lisa, one of the participants in this study, demonstrates.

As in most qualitative studies, only a selective portrait of the experiences of live-in caregivers in Canada was painted, but one that will nevertheless add a deeper meaning to the existing body of literature on the subject. No sweeping generalization is possible from this study, as only four interviews were conducted.

Neoliberalism is hard to by-pass when discussing the settlement of newcomers. The structural constraints mentioned in the problem approach greatly impacted the experiences of the participants interviewed. Although there is no reason to believe that this economic, political, and social trend will be reversed any time soon, this paper does demonstrate that there is room to manoeuvre from within: this immigrant-unfriendly structure, and that grass-roots small associations may be the key to promote a sense of community and 'normalcy' in live-in caregivers lives. 
Appendix A: Recruitment Flyer

Are you a woman of Filipino origin?

Did you come to Canada under the Live-in Caregiver Program?

Are you currently working in Toronto as a nanny?

Would you like to participate in a study that could help shape immigration policy for foreign domestic workers and get $\$ 30$ for your time?

My name is Chantal Dansereau-Cahill, and I am a graduate student at Ryerson University in a program called Immigration and Settlement Studies. I am doing a study on the social networks of Filipina nannies, and the ways used to adapt to your new lives and feel at home in Canada. I am interested in finding out more about your experience in this country. My questions will relate to the activities you do outside of your work, the people you socialize with, and how you feel about your life in Canada.

Your participation in this study is voluntary and confidential. You will get a $\$ 30$ compensation for your time.

If you would like more information or to participate, please call me and we will set up a time and date convenient for both of us. The interview will last approximately one hour, and could be held at Ryerson University, the Kababayan Community Center, or at any other private location where you would feel comfortable. The interview will be recorded, however, no names, personal c information or identifiable characteristics will be used in my final paper, and the tapes will be destroyed upon completion of my program of study.

If you have any questions concerning your rights as a human subject and participant in this study, please contact:

Alex Karabanow,

Interim at the Ryerson Research Ethics Board

(416) $979-5000$ ext. 7112

alex.karabanow@ryerson.ca

Thank you for your time an interest in my research. I am looking forward to meeting you.

Chantal Dansereau-Cahill

(647) 505-0756; chantalcahill@hotmail.com 
Appendix B: Consent Form

Filipina Live-in Caregivers' Experiences of Adaptation and Settlement in Toronto

\section{Consent Agreement}

You are being asked to participate in a research study. Before you give your consent to be a volunteer, it is important that you read the following information and ask as many questions as necessary to be sure you understand what you will be asked to do:

The researcher and interviewer is Chantal Dansereau-Cahill, graduate student in Immigration and Settlement Studies (ISS) at Ryerson University.

This study looks at the lives of Filipina nannies who came in Canada under the Live-in Caregiver Program, and analyses the ways they use to adapt to their new lives, and foster their settlement into Canadian society. The interview will last approximately one hour. None of the procedures used in this study are experimental in nature. The only experimental aspect is the gathering of information for the purpose of analysis.

Potential personal benefits from participating in this study are on a psychological level. It may be emotionally rewarding to openly discuss your life in this country and realize the complexity of networks you have created. On a wider scale, your participation will provide a deeper understanding of the agency and activism displayed by Filipina nannies in Canada, and might improve the services available to assist Filipina nannies in their integration in Canada. I cannot guarantee, however, that you will receive any benefits from participating in this study other than the $30 \$$ compensation. Potential risks include feeling uncomfortable or stressed.

The interview could take place in a room at Ryerson University or at any other location where you feel comfortable, and will be recorded. What you say is totally confidential. The only people who will have access to the tapes are the primary researcher (Chantal Dansereau-Cahill), and her supervisor (Vappu Tyyska). What is said in the interviews will then be written down to make the data analysis easier. If you feel uncomfortable with being audio-taped, I can take written notes only. If I quote something you say in my research paper, I will not use your name or any identifiable characteristics. The tapes and verbatim transcripts will be kept confidential and secure in the safe in my house, and destroyed after the completion of my graduate course.

Participation in this study is voluntary. Your choice of whether or not to participate will not influence your future relations with your employer, or Ryerson University. If you decide to participate, you are free to withdraw your consent and to stop your participation at any time. At any particular point in the study, you may refuse to answer any particular question or stop 
participation altogether.

If you have any questions about the research now, please ask. If you have questions later about the research, you may contact:

Vappu Tyyska

416-979-5000 ext. 6208
Chantal Dansereau-Cahill

(647) 505-0756

If you have questions regarding your rights as a human subject and participant in this study, you may contact the Ryerson University Research Ethics Board for information.

Alex Karabanow

Research Ethics Board

c/o Office of the Vice President, Research and Innovation

Ryerson University

350 Victoria Street, Toronto, ON, M5B 2K3

(416) 979-5000 ext. 7112

alex.karabanow@ryerson.ca

I have read and understood this consent form

Signature of Participant / Date

I agree to have this interview audio-taped

Signature of Participant / Date

A copy of this consent form is given to the participant

Signature of Researcher / Date 
Appendix C: Basic Demographic Information Form

Filipina Live-in Caregivers' Experiences of Adaptation and Settlement in Toronto

Basic Demographic Information of Participants

Age:

Arrival Date in Canada (month and year) :

Country of origin:

Number of families you have worked for, including the current one:

Number of children you care for in Canada:

Marital Status (circle one): Single

Married

Divorced

Widowed

Do you have any children:

If yes, how may and how old are they:

If yes, in which country are they currently living: 
Appendix D: Interview Guide

Tell me about your experience in Canada.

What activities do you do in your spare time, when you do not work?

Who are the people involved in these activities?

Did you meet them in Canada or in the Philippines?

Do you spend time with people from outside the Filipino community?

How did you meet these people?

Do you attend any Philippine community event?

With whom do you attend these activities?

How did you learn about (the particular event mentioned)?

How do you feel when you attend (the particular event mentioned)?

What does it mean to you to have this friend (or group of friends, depending on the answer) you can share time with outside of work?

How do you think these activities help you adapt to Canada?

Do you feel at home here?

Do you plan to apply for permanent residency once you have completed the requirements of the Live-in Caregiver Program, or go back home, or do something else? 


\section{References}

Arat-Koç, S. (1997). From "Mothers of the Nation" to Migrant Workers in Not One of the Family: Foreign Domestic Workers in Canada by A. Bakan and D. Stasiulis (Eds.) Toronto: University of Toronto Press, pp. 53-79.

Arat-Koç, S. (1999). Neo-Liberalism, State Restructuring and Immigration: Changes in Canadian Policies in the 1990s. Journal of Canadian Studies. Vol. 34(2) pp. 31-53.

Arneil, B. (2006).Diverse Communities: The Problem with Social Capital. New York: Cambrige University Press.

Baines, D. (2008). Race, Resistance, and Restructuring: Emerging Skills in the New Social Services. Social Work. Vol. 53(2) pp.123-132.

Baines, D. (2010). Neoliberal Restructuring, Activism/Participation, and Social Unionism in the nonprofit Social Services. Nonprofit and Voluntary Sector Quarterly. Vol. 39(1) pp. 10-28.

Bakan, A. B. and Stasiulis, D. (1997). "Introduction" and "foreign Domestic Worker Policy in Canada and the Social Boundaries of Modern Citizenship". in Not One of the Family: Foreign Domestic Workers in Canada, by A. B. Bakan and D. Stasiulis (Eds.) Toronto: University of Toronto Pres, pp. 1-52

Bakan, A. B. and Stasiulis, D. (2005). Negotiating Citizenship: Migrant Women in Canada and the Global System. Toronto: University of Toronto Press.

Barrera, M. Li, S. A. Chassin, L. (1998). 'Exploring Adolescents'. Vulnerability to Life Stress and Parental Alcoholism: The Role of Ethnicity and Family Conflict" in H. I. McCubbin et als (Eds.) Resiliency in Native American and Immigrant Families. London: Sage Publications. 
Bedolla, L. G. (2007). "Race, Social Relations, and the Study of Social Capital", in James Jennings (Eds.) Race, Neighbourhoods, and the Misuse of Social Capital. New York: Palgrave MacMillan. pp. 7-21.

Bielsky, Z. (2009). Family Factotum. Retrieved on June $7^{\text {th }} 2009$ from the Globe and Mail website at http://www.theglobeandmail.com/life/article1140103.ece

Brazao, D. Cribb, R. (2009). Nannies Trapped in Bogus Jobs. Retrieved on July $2^{\text {nd }} 2009$ from The Toronto Star website at http://www.thestar.com/article/602352

Citizenship and Immigration Canada (2007). Annual Report to Parliament on Immigration. Retrieved July $5^{\text {th }} 2009$ from http://www.cic.gc.ca/english/resources/publications/annualreport2008/section3.asp\#part3_3

Chang, G. (2000). "Introduction" Disposable Domestics: Immigrant women Workers in the Global Economy. Cambridge, Mass.: South End Press, pp. 1-20.

Cheng, S-J. A (1999). "Labour Migration and International Sexual Division of Labor: A Feminist Perspective" in Gregory A. Kelson and Debra L. DeLaet (Eds.) Gender and Immigration. New York: New York University Press, pp.38-58.

Daenzer, P. M. (1997). "An Affair Between Nations: International Relations and the Movement of Household Service Workers" in Not One of the Family: Foreign Domestic Workers in Canada, by A. B. Bakan and D. Stasiulis (Eds.) Toronto: University of Toronto Press,' pp.81-118.

Dictionary of the Social Sciences (2004). Athabasca University online dictionary, retrieved June $20^{\text {th }} .2010$ from http://bitbucket.icaap.org/dict.pl

Dyer, S. McDowell, L. Batnitzky, A. (2008). "Emotional labour/body work: The caring labours of migrants in the UK's National Health Service". Geoforum 39 (6), pp. 2030-2038. 
Ehrenreich, B. Hochschild, A. R. (Eds.) (2002). Global Woman: Nannies, Maids, and Sex-

Workers in the New Economy. New York: Henry Holt and Company.

Fudge, J. (1997). "Little Victories and Big Defeats: The Rise and Fall of Collective Bargaining Rights for Domestic Workers in Ontario", in Not One of the Family: Foreign Domestic Workers in Canada, by A. B. Bakan and D. Stasiulis (Eds.) Toronto: University of Toronto Pres, pp. 118-145.

Garcia, M. A. (2005). “The Road to Empowerment in Toronto's Filipino Community: Moving from Crisis to Community Capacity-Building".

Giles, W. Arat-Koç, S. (Eds.) (1994). Maid in the Market: Women's Paid Domestic Labour. Halifax: Fernwood Publishing.

Harzig, C. (2003). "MacNamara's DP Domestics: Immigration Policy Makers Negociate Class, Race and Gender in the Aftermath of World War II". Social Politics (Spring 2003) pp. 2345).

Hero, R. E. (2007). Racial Diversity and Social Capital: Equality and Community in America. New York: Cambridge University Press.

Human Resources and Skills Development Canada (HRSDC) (2010). Temporary Foreign Workers. Retrieved on July $2^{\text {nd }} 2010$. from http:/www.rhdcc-hrsdc.gc.ca/eng/ workplaceskills/foreign_workers/index.shtml.

Jennings, J. (2007). Race, Neighbourhoods, and the Misuse of Social Capital. New. York: Palgrave MacMillan.

Kelly, P. (2008). "Filipinos in Canada: Economic Dimensions of Immigration and Settlement" Joint Center of Excellence for Research in Immigration and Settlement. CERIS Working Paper 48 - Toronto: The Ontario Metropolis Centre 
Macklin, A. (1994). On the Inside Looking In: Foreign Domestic Workers in Canada in Maid in the Market: Women's Paid Domestic Labour by W. Giles and S. Arat-Koç (Eds). Halifax: Fernwood Publishing, pp.13-39.

McCubbin, H. I. Thompson, E. A. Thompson, A. I. Fromer, J. E. (1998). Resiliency in Native American and Immigrant Families. London: Sage Publications

Miller, W. L. and Crabtree, B. F. (2004). Doing Qualitative Research. Newbury Park, California: Sage Publications.

Neuman, W. L. (2006). Social Research Methods - Qualitative and Quantitative Approaches, Sixth Edition. Toronto: Pearson.

Oxman-Martinez, J. Hanley, J. Cheung, L. (2004). Another Look at the Live-in-Caregivers Program. Centre de Recherche Interuniversitaire'de Montréal sur l'Immigration, - l'Intégration et la Dynamique Urbaine. Publication IM - n.24, September 2004.

Parrenas, R. S. (2002). The Care-Crisis in the Philippines: Children and Transnational Families in the New Global Economy, in Global Woman-Nannies, Maids, and Sex-Workers in the New Economy by B. Ehrenreich and A. R. Hochschild. New York: Henry Holt and Company, pp. 39-54.

Philippines-Canada Human Resource Development Program (PCHRD) (1996). Uneven Gains: Filipina Domestic Workers in Canada. Ottawa: The North-South Institute.

Putnam, R. D. (1995). "Bowling Alone: America's Declining Social Capital" in Journal of Democracy. Vol. 6(1), pp. 65-78.

Putnam, R. D. (2000). Bowling Alone: The Collapse and Revival of American Community: New York: Simon \& Schuster. 
Pratt, G. (1999). "From registered nurse to registered nanny: Discursive geographies of Filipina domestic workers in Vancouver, B.C. " Economic Geography. Vol.75(3) pp. 215-237.

Pratt, G. (2002). "Between Homes: Displacement and Belonging for Second Generation Filipino-Canadian Youths". Vancouver Center for Excellence - Research on Immigration. and Integration in the Metropolis. Working Paper Series No. 02-13.

Pratt, G. (2008). "Deskilling Across the Generations: Reunification Among 'Transnational Filipino Families in Vancouver". Metropolis British Columbia - Centre of Excellence for Research on Immigration and Diversity. Working Paper Series No. 08-06.

Schecter, T. (1998). Race, Class, Women and the State: The Case of Domestic Labour. Montreal: Black Rose Book.

Schuller, T. Field, J. Baron, S. (2000). "Social Capital: A Review and Critique" in Social Capital: Critical Perspective by T. Schuller, J. Field, S. Baron (Eds.) Oxford: Oxford University Press, pp. 1-55.

Spitzer, D. L. Torres, S. (2008). Gender-Based Barriers to Settlement and Integration for Livein-Caregivers: A Review of the Literature. Toronto: Center for Excellence in Research on Immigration and Settlement - The Ontario Metropolis Center, Working Paper no. 71.

Thobani, S. (2000). Closing Ranks: Racism and Sexism in Canada's Immigration Policy. Race and Class. Vol. 42(1) pp. 35-55.

Tyyska, V. (2010). "Sri Lankan Tamil Families in Canadian Diaspora: From Family Problems to Family Resiliency', in Beyond Nations: Diaporas, Transnationalism and Global Engagement by R. Cheran and S. Guruge (Eds.). Colombo: International Centre for Ethnic Studies. 
Velasco, P. M. (1997). 'We Can Still Fight Back': Organizing Domestic Workers in Toronto, in Not One of the Family: Foreign Domestic. Workers in Canada, by A. B. Bakan and D. Stasiulis (Eds.) Toronto: University of Toronto Pres, pp. 157-164.

Trudeau, D. (2008). "Junior Partner or Empowered Community? The role of Non-Profit Social Service Providers amidst State Restructuring in the US". Urban Studies Journal Limited. Vol. 45(13) pp. 2805-2827.

Yeates, N. (2005). “A Global Political Economy of Care". Social Policy and Society 4(2), pp. 227-234. 